\title{
Tomato Yield and Fruit Size Did Not Respond to $P$ Fertilization of a Sandy Soil Testing Very High in Mehlich-1 P
}

\author{
George Hochmuth ${ }^{1}$ and Osmar Carrijo ${ }^{2}$ \\ Horticultural Sciences Department, University of Florida, Gainesville, \\ FL 32611-0690
}

\author{
Ken Shuler ${ }^{3}$ \\ Cooperative Extension Service, Palm Beach County, 559 North Military Trail, \\ West Palm Beach, FL 33415
}

Additional index words. soil testing, Lycopersicon esculentum, tissue testing

\begin{abstract}
Tomato (Lycopersicon esculentum Mill.) was grown in southeastern Florida on sandy soils that tested very high in Mehlich-1 $P$ to evaluate the yield response to $P$ fertilization. One location was used in 1995-96, another in 1996-97. Prefertilization soil samples contained 290 (location 1) and 63 (location 2) $\mathrm{mg} \cdot \mathrm{kg}^{-1}$ Mehlich-1 P. Both soil test results were interpreted as very high in $P$, and $P$ fertilizer was not recommended for the crop. Fertilizer treatments at both sites were $0,25,50,100,150$, and $200 \mathrm{~kg} \cdot \mathrm{ha}^{-1} \mathrm{P}$. Neither total marketable yield nor yield in any fruit size category was affected by $P$ fertilization in either season. Amounts of cull (undersized or misshapened) fruits increased quadratically with $P$ fertilization in the second season. Whole-leaf $P$ concentrations increased linearly or quadratically with $P$ application, depending on sample periods, and were always above sufficiency values. Although many tomato growers apply $P$ fertilizer irrespective of soil test recommendations, our results showed that added $P$ was not needed on soils testing very high in P. Furthermore, withholding $P$ applications to soils with high $P$ concentrations will minimize potential $P$ pollution of surface water and groundwater.
\end{abstract}

Tomato is produced on $\approx 20,000$ ha annually in Florida with a value of $\approx \$ 0.5$ billion (Witzig and Pugh, 1997). Tomato is one of the most expensive vegetable crops produced in Florida, with fertilizer accounting for $\approx 5 \%$ (\$800 per ha) of the preharvest costs (Smith and Taylor, 1995). Average fertilizer applications for tomato in Florida are reported to be $250 \mathrm{~kg} \cdot \mathrm{ha}^{-1} \mathrm{~N}, 90 \mathrm{~kg} \cdot \mathrm{ha}^{-1} \mathrm{P}$, and $360 \mathrm{~kg} \cdot \mathrm{ha}^{-1} \mathrm{~K}$ (National Agricultural Statistics Service, 1990). Phosphorus is applied by growers even when soil tests indicate that no $\mathrm{P}$ fertilizer is needed.

The reasoning behind the regular $\mathrm{P}$ fertilization is the belief that extra fertilization insures against perceived fertilizer-related reductions in yield and quality, or that the soil $\mathrm{P}$ reserve must be maintained at a high level with continuous $\mathrm{P}$ additions. This philosophy is consistent with the "buildup and maintenance" approach to soil fertility (Fixen and Grove, 1990). Phosphorus leaches from soils with

\footnotetext{
Received for publication 9 July 1998 . Accepted for publication 18 Sept. 1998. Florida Agricultural Experiment Station Journal Series no. 6421. The cost of publishing this paper was defrayed in part by the payment of page charges. Under postal regulations, this paper therefore must be hereby marked advertisement solely to indicate this fact. ${ }^{1}$ Professor.

${ }^{2}$ Visiting Research Scientist: EMBRAPA-CNPH. Km 09 rod. BR 060 Cx. Postal 0218. 70059-970 Brasilia-DF BRAZIL.

${ }^{3}$ County Agent.
}

moderate to low $\mathrm{P}$ fixing capacities (Rhue and Everett, 1987). Continued P applications to these soils could result, with time, in significant $\mathrm{P}$ losses to surface and groundwater. In addition, $\mathrm{P}$ contamination of surface water could result when erosion moves P-laden soil into bodies of water. The Univ. of Florida Extension Soil Testing Laboratory employs the Mehlich-1 (Mehlich, 1953) soil test extractant for sandy soils; this extractant has been calibrated for vegetable crop use (Hanlon and Hochmuth, 1992; Hochmuth and Hanlon, 1995).

Considerable field research and demonstration work has been done on $\mathrm{P}$ fertilization of vegetables in Florida. The most recent of these studies showed that crops growing on soils with high (>30 mg. $\mathrm{kg}^{-1}$ ) Mehlich-1 extractable $\mathrm{P}$ did not respond to $\mathrm{P}$ fertilization (Hochmuth et al., 1993a; 1993b; Locascio et al., 1996; Rhoads et al., 1990; Rhue et al., 1981), supporting older observations that $P$ had accumulated in vegetable lands because of continuous P fertilization (Hortenstine, 1966; Westgate et al., 1958). Residual soil P can benefit crop production (Forbes and Westgate, 1962; Novais and Kamprath, 1978; Peck et al., 1987 ) as long as calibrated soil tests can predict crop response to $\mathrm{P}$ fertilization of a specific soil having a specific soil-test $\mathrm{P}$ index (Anderson, 1983; Hatzell and Blue, 1981; Kurtz, 1981; Sartain et al., 1979; Wolf and Baker, 1985). Phosphorus availability depends on several factors, including amount of $\mathrm{P}$ available in the soil (Fixen and Grove, 1990; Tisdale etal., 1985), soil temperature (Locascio and Warren, 1960), and P fertilizer placement (Barber and Kovar, 1985; Kovar and Barber, 1987; Locascio et al., 1960). Even though tomato growers in Florida have high-P soils and are placing $P$ in such a manner to allow for efficient $\mathrm{Putilization}$, they still feel that largerthan-recommended amounts of $\mathrm{P}$ are required. This research was conducted to determine if this continual $\mathrm{P}$ fertilization of high-P soils was justified for tomato production.

\section{Materials and Methods}

Experiments were conducted in the winter tomato production seasons of 1995-96 (Expt. 1) and in 1996-97 (Expt. 2) on two commercial tomato farms in southeastern Florida. Expt. 1 was conducted in Boynton Beach, Fla., on an Oldsmar sand (Alfic, Arenic, Haplaquods, sandy, siliceous, hyperthermic) and Expt. 2 in Ft. Pierce, Fla., on a Malabar fine sand (Grossarenic Ochraqualfs, siliceous, loamy, hyperthermic).

Fields used for both experiments were fallow for 4 to 6 months prior to each tomato crop, with weeds controlled by periodic disking. Soil preparation consisted of disking and laser-leveling. Prefertilization soil samples were taken of the upper $15 \mathrm{~cm}$ of soil and analyzed for $\mathrm{P}$ by the Mehlich-1 extraction method (Georgia Agricultural Experiment Station, 1983; Hanlon et al., 1994).

Before fertilization, the soil at Boynton Beach in Winter 1995-96 tested $290 \mathrm{mg} \cdot \mathrm{kg}^{-1}$ Mehlich-1 P, which was very high in $\mathrm{P}$ content. The soil $\mathrm{pH}$ was 7.2 in a 2 water $: 1$ soil mixture. Current Mehlich-1 soil test $P$ calibration used by the Univ. of Florida places any soil test value $>60 \mathrm{mg} \cdot \mathrm{kg}^{-1}$ in the very high category, and any soil test value between 30 and $60 \mathrm{mg} \cdot \mathrm{kg}^{-1}$ in the high category, and recommends no $\mathrm{P}$ fertilization for soils in either category (Hochmuth and Hanlon, 1995).

The soil at the second site (Expt. 2) tested $63 \mathrm{mg} \cdot \mathrm{kg}^{-1}$ Mehlich-1 P, which was a value near the breakpoint value $\left(60 \mathrm{mg} \cdot \mathrm{kg}^{-1}\right)$ between high and very high Mehlich-1 P categories. The soil $\mathrm{pH}$ was 7.0 in a 2 water : 1 soil mixture.

On 2 Nov. 1995 and 31 Jan. 1997, preplant fertilizer mixtures containing varying amounts of $\mathrm{P}$ were broadcast by hand in a 50 -cm-wide band on the soil surface of the area to become the future raised, mulched planting bed. The fertilizer mixture in 1995 consisted of potassium magnesium sulfate, ammonium nitrate, magnesium sulfate, manganese sulfate, iron sulfate, zinc sulfate, and sodium borate. Rates of nutrients supplied in the preplant bed mix were $\left(\mathrm{kg} \cdot \mathrm{ha}^{-1}\right) 20 \mathrm{~N}, 36 \mathrm{~K}, 20 \mathrm{Mg}, 4 \mathrm{Mn}, 2 \mathrm{Zn}$, $2 \mathrm{Fe}$, and $1 \mathrm{~B}$. The same materials were used for the fertilizer mixture in 1997 at rates $\left(\mathrm{kg} \cdot \mathrm{ha}^{-1}\right)$ of $40 \mathrm{~N}, 65 \mathrm{~K}, 60 \mathrm{Mg}, 4 \mathrm{Mn}, 2 \mathrm{Zn}, 2$ $\mathrm{Fe}$, and $1 \mathrm{~B}$.

The $P$ rates used were $0,25,50,100,150$, and $200 \mathrm{~kg} \cdot \mathrm{ha}^{-1} \mathrm{P}$ supplied from triple superphosphate. Fertilizer blends were applied to the soil and incorporated by bedding discs during the bed-making process. Beds were formed on $1.5-\mathrm{m}$ centers and were $15 \mathrm{~cm}$ in height and $75 \mathrm{~cm}$ across the top surface. The 
soil was fumigated with $400 \mathrm{~kg} \cdot \mathrm{ha}^{-1}$ of a $98 \%$ methyl bromide : $2 \%$ trichloromethane (chloropicrin) mixture by injecting the fumigant into the soil during the bed-making process. Simultaneously, two grooves, $4 \mathrm{~cm}$ deep, were made in the surface of the bed, each $25 \mathrm{~cm}$ from the center of the bed, into which was placed a mixture of $\mathrm{N}$ and $\mathrm{K}$ fertilizer (determined by the commercial tomato grower) consisting of potassium nitrate, potassium sulfate, calcium nitrate, and ammonium nitrate to supply an additional $340 \mathrm{~kg} \cdot \mathrm{ha}^{-1} \mathrm{~N}$ and 570 $\mathrm{kg} \cdot \mathrm{ha}^{-1} \mathrm{~K}$ in 1995 and $285 \mathrm{~kg} \cdot \mathrm{ha}^{-1} \mathrm{~N}$ and 390 $\mathrm{kg} \cdot \mathrm{ha}^{-1} \mathrm{~K}$ in 1997. Finally, the beds were covered with black polyethylene mulch.

On 1 Dec. 1995 and 10 Feb. 1997, 'Solimar' (Asgrow Seed Co., Kalamazoo, Mich.) tomato transplants were planted through the mulch in a single row $56 \mathrm{~cm}$ apart in 1995 and $64 \mathrm{~cm}$ apart in 1997. Experimental plots were single rows $9.1 \mathrm{~m}$ in length in both experiments.

On 8 Dec. 1995 (35 d after P fertilizer application ) and on 6 Mar. 1997 (34 d after P application), soil samples were taken from the beds in each plot to a depth of $15 \mathrm{~cm}$. After final harvest in each experiment, soil samples were collected from the upper $15 \mathrm{~cm}$ of the soil in the bed and analyzed for P by Mehlich-1 extraction technique (Hanlon et al., 1994).

Except for fertilization practices, tomatoes were grown with cultural methods typical of those recommended for southeastern Florida
(Hochmuth, 1990; Hochmuth and Maynard, 1996). Plants were staked and tied two times during the first season and four times during the second season, using recommended staking and tying procedures. Irrigation was by subsurface irrigation from a raised water table maintained at 50 to $60 \mathrm{~cm}$ below the surface of the bed. This practice typically maintains the soil moisture potential at -8 to $-10 \mathrm{kPa}$ at a depth of $15 \mathrm{~cm}$.

Plant diseases and insects were controlled by applications of standard recommended pesticides (Hochmuth and Maynard, 1996).

Whole-leaf tissue samples (sixth leaf from the branch tip) were collected for P analyses three times during each experiment, at flowering of the first and third fruit clusters, and at first harvest. Samples were collected on 12 Jan. 1995; 9 Feb. and 8 Mar. 1996; and on 24 Mar., 14 Apr., and 1 May 1997. Six leaves were taken for each experimental plot, dried in a forced-draft oven, and ground in a Wiley mill. A sample of the ground tissue was digested in sulfuric acid and hydrogen peroxide on a heating block and analyzed for $\mathrm{P}$ by plasma emission spectroscopy (Hanlon et al., 1994).

Tomatoes were harvested at the maturegreen stage (Sherman, 1990) four times in the first experiment and three times in the second. Harvests were made on 14 and 26 Mar., and 10 and 23 Apr. 1996; and on 1, 9, and 19 May 1997. Fruits were graded into marketable and

Table 1. Yield response of tomato to $\mathrm{P}$ fertilization of a sandy soil testing very high in Mehlich-1 extractable P, Boynton Beach, Fla., Winter 1995-96 (Expt. 1).

\begin{tabular}{|c|c|c|c|c|c|c|}
\hline \multirow{2}{*}{$\begin{array}{l}\text { P rate }^{\mathrm{z}} \\
\left(\mathrm{kg} \cdot \mathrm{ha}^{-1}\right)\end{array}$} & \multicolumn{5}{|c|}{ Yield $\left(\mathrm{t} \cdot \mathrm{ha}^{-1}\right)^{\mathrm{y}}$} & \multirow{2}{*}{$\begin{array}{l}\text { Avg mkt. } \\
\text { fruit wt }(\mathrm{g})\end{array}$} \\
\hline & Extra large & Large & Medium & Total mkt. & Cull & \\
\hline \multicolumn{7}{|c|}{ First harvest } \\
\hline 0 & 8.9 & 6.7 & 2.9 & 18.5 & 4.8 & 185 \\
\hline 25 & 9.2 & 6.4 & 2.8 & 18.4 & 3.5 & 185 \\
\hline 50 & 10.0 & 5.1 & 2.6 & 17.7 & 4.7 & 190 \\
\hline 100 & 10.0 & 6.3 & 2.5 & 18.8 & 4.1 & 185 \\
\hline 150 & 9.4 & 7.2 & 2.7 & 19.3 & 3.3 & 185 \\
\hline 200 & 9.2 & 5.7 & 3.1 & 18.0 & 4.1 & 180 \\
\hline Significance & NS & NS & NS & NS & NS & NS \\
\hline \multicolumn{7}{|c|}{ Season (four harvests) } \\
\hline 0 & 15.8 & 20.8 & 14.0 & 50.6 & 18.8 & 150 \\
\hline 25 & 16.7 & 18.8 & 13.5 & 49.0 & 19.9 & 155 \\
\hline 50 & 18.3 & 17.9 & 14.2 & 50.4 & 17.7 & 155 \\
\hline 100 & 16.5 & 18.5 & 14.0 & 49.0 & 18.3 & 155 \\
\hline 150 & 17.5 & 20.6 & 14.5 & 52.6 & 18.1 & 155 \\
\hline 200 & 17.1 & 19.5 & 14.3 & 50.9 & 18.7 & 150 \\
\hline Significance & NS & NS & NS & NS & NS & NS \\
\hline
\end{tabular}

${ }^{\mathrm{z}}$ Prate calculated on basis of planting beds on 1.5-m centers but incorporated in the soil in the raised, mulched bed measuring $15 \mathrm{~cm}$ in height and $75 \mathrm{~cm}$ wide.

y Diameters: extra large $(>6.99 \mathrm{~cm})$; large $(6.35-7.06 \mathrm{~cm})$; and medium $(5.72-6.43 \mathrm{~cm})$.

${ }^{\text {Ns} N o n s i g n i f i c a n t . ~}$ cull (undersized and misshapened) fruits. Marketable fruits were further graded into size categories of extra large (>6.99 cm diam.), large $(6.35-7.06 \mathrm{~cm})$, and medium $(5.72-6.43$ $\mathrm{cm})$ as specified in the Florida Tomato Marketing Order (Florida Tomato Commission, 1997a, 1997b).

Data were analyzed by analysis of variance. When treatment effects were significant, trends were modeled with regression analysis (SAS Institute, 1985).

\section{Results and Discussion}

Yield response, Expt. 1. Neither early (first harvest) nor total (four harvests) marketable yields were affected by $\mathrm{P}$ fertilization (Table 1). Early-season yields averaged 9.5 (extra large), 6.2 (large), and 2.8 (medium) $\mathrm{t} \cdot \mathrm{ha}^{-1}$ and total-season yields averaged 17.0 (extra large), 19.4 (large), and 14.1 (medium) $t \cdot h^{-1}$. Total marketable yields were 18.5 (early) and 50.4 (season) $t \cdot h a^{-1}$. These yields were very good by Florida standards as average yield was 34.1 $\mathrm{t} \cdot \mathrm{ha}^{-1}$ in the 1995-96 tomato season (Witzig and Pugh, 1997). Total-season marketable fruit yield was $72 \%$ large- and extra-large-sized fruits, a proportion desired by commercial tomato growers. In another study on a nearby farm, tomato yield did not respond to $\mathrm{P}$ fertilization of a sandy soil testing $220 \mathrm{mg} \cdot \mathrm{kg}^{-1}$ Mehlich-1 P (Shuler and Hochmuth, 1995).

Amounts of cull fruits and average marketable fruit size were not affected by P fertilization (Table 1). Cull fruit production early in the season was small $(\approx 18 \%$ of total early fruit production) vs. $27 \%$ for the entire season. These amounts of culls are not typical, but the 1995-96 season was uncharacteristically cold with several near-freeze events on 24 Dec. 1995; and 8-12 Jan., 4-6 Feb., and 18-19 Feb. 1996. These cool temperatures resulted in production of large amounts of undersized and misshapen fruits. Average fruit weight $[185 \mathrm{~g}$ (early) and $153 \mathrm{~g}$ (season)], was not affected by $\mathrm{P}$ fertilization.

Whole-leaf $\mathrm{P}$ concentrations increased quadratically with an increase in $\mathrm{P}$ fertilization for the samples taken at first flower cluster and at third flower cluster stages, and linearly with $\mathrm{P}$ fertilization for samples taken at first harvest (Table 2). All whole-leaf P concentrations at all sampling periods were above published sufficiency ranges of 2 to $4 \mathrm{~g} \cdot \mathrm{kg}^{-1} \mathrm{P}$ (Hochmuth et al., 1991; Jones et al., 1991). The $\mathrm{P}$ concentrations early in the season were especially high, documenting that tomato plants

Table 2. Response of tomato whole-leaf P concentrations to P fertilization of sandy soils testing very high in Mehlich-1 P in two experiments in Florida.

\begin{tabular}{|c|c|c|c|c|c|c|c|c|c|c|}
\hline \multirow[b]{2}{*}{ Expt. } & \multirow[b]{2}{*}{ Year } & \multirow[b]{2}{*}{ Location } & \multirow{2}{*}{$\begin{array}{c}\text { Seasonal sampling } \\
\text { period }\end{array}$} & \multicolumn{6}{|c|}{$\mathrm{P}$ rate $\left(\mathrm{kg} \cdot \mathrm{ha}^{-1}\right)^{\mathrm{z}}$} & \multirow[b]{2}{*}{ Significance } \\
\hline & & & & 0 & 25 & 50 & 100 & 150 & 200 & \\
\hline & & & & & & & e-leaf & $\mathrm{cn}(\mathrm{g}$ & & \\
\hline \multirow[t]{3}{*}{1} & 1995-96 & Boynton Beach & First cluster flowering & 6.2 & 6.8 & 7.7 & 8.0 & 9.0 & 9.2 & $\mathrm{~L}^{* *} \mathrm{Q}^{*}$ \\
\hline & & & Third cluster flowering & 4.5 & 5.2 & 5.5 & 6.7 & 7.5 & 7.4 & $\mathrm{~L}^{* *} \mathrm{Q}^{*}$ \\
\hline & & & First harvest & 3.2 & 3.0 & 3.5 & 4.0 & 4.3 & 4.8 & $\mathrm{~L}^{* *}$ \\
\hline \multirow[t]{3}{*}{2} & 1996-97 & Ft. Pierce & First cluster flowering & 6.3 & 6.8 & 7.2 & 7.3 & 7.3 & 7.0 & $\mathrm{~L}^{*} \mathrm{Q}^{* *}$ \\
\hline & & & Third cluster flowering & 5.2 & 5.3 & 5.8 & 6.0 & 6.7 & 6.8 & $\mathrm{~L}^{* *}$ \\
\hline & & & First harvest & 3.8 & 3.8 & 4.3 & 4.5 & 5.5 & 5.3 & $\mathrm{~L}^{* *}$ \\
\hline
\end{tabular}

${ }^{2} \mathrm{P}$ rate calculated on basis of planting beds on $1.5-\mathrm{m}$ centers but incorporated in the soil in the raised, mulched bed measuring $15 \mathrm{~cm}$ in height and $75 \mathrm{~cm}$ wide. Ns, *, ** Nonsignificant or significant at $P \leq 0.05$ or 0.01 , respectively. Regression equations contained significant linear (L) or quadratic (Q) terms. 
growing on this soil, very high in Mehlich-1 P, had ample $\mathrm{P}$ available to them without fertilization.

Yield response, Expt. 2. Marketable yields were not affected by $\mathrm{P}$ fertilization at this site in the 1996-97 winter season (Table 3). Yields were higher than in Expt. 1, possibly due partly to the new site on which few tomato crops had previously been grown, but also partly to a much more favorable growing season with no cold periods. Early fruit yields averaged 37.2 (extra large), 10.5 (large), and 0.2 (medium) $\mathrm{t} \cdot \mathrm{ha} \mathrm{a}^{-1}$. Total marketable early yield averaged $47.9 \mathrm{t} \cdot \mathrm{ha}^{-1}$. For the season, the average yields were 55.4 (extra large), 23.0 (large), and 12.1 (medium) $\mathrm{t} \cdot \mathrm{ha}^{-1}$. Average total marketable season yield was $90.4 \mathrm{t} \cdot \mathrm{ha}^{-1}$. Large and extra large fruit production and $87 \%$ of the total-season fruit production.

Amounts of cull fruits increased quadratically with P fertilization (Table 3). Although affected by $P$ fertilization, amounts of cull fruits were very low overall, averaging $4 \%$ of early fruit and $3 \%$ of total-season fruit production. Average fruit weight was not affected by $P$ fertilization, averaging $210 \mathrm{~g}$ per fruit in the first harvest and $193 \mathrm{~g}$ per fruit for the season (Table 3).

Whole-leaf $\mathrm{P}$ concentrations at first flower cluster increased quadratically with $\mathrm{P}$ applied (Table 2), and concentrations at third cluster and at first harvest increased linearly. All

Table 3. Response of tomato to P fertilization of a sandy soil testing very high in Mehlich-1 extractable P, Ft. Pierce, Fla., Winter 1996-97 (Expt. 2).

\begin{tabular}{|c|c|c|c|c|c|c|}
\hline \multirow{2}{*}{$\begin{array}{l}\text { Prate }^{z} \\
\left(\mathrm{~kg} \cdot \mathrm{ha}^{-1}\right)\end{array}$} & \multicolumn{5}{|c|}{ Yield $\left(\mathrm{t} \cdot \mathrm{ha}^{-1}\right)^{\mathrm{y}}$} & \multirow{2}{*}{$\begin{array}{l}\text { Avg mkt. } \\
\text { fruit wt }(\mathrm{g})\end{array}$} \\
\hline & Extra large & Large & Medium & Total mkt. & Cull & \\
\hline \multicolumn{7}{|c|}{ First harvest } \\
\hline 0 & 37.1 & 9.2 & 0.0 & 46.3 & 0.8 & 210 \\
\hline 25 & 38.6 & 10.9 & 0.2 & 49.7 & 0.7 & 205 \\
\hline 50 & 36.4 & 9.3 & 0.1 & 45.8 & 1.6 & 210 \\
\hline 100 & 39.8 & 12.0 & 0.3 & 52.1 & 2.6 & 215 \\
\hline 150 & 35.6 & 11.1 & 0.4 & 47.1 & 2.5 & 210 \\
\hline 200 & 35.5 & 10.7 & 0.1 & 46.3 & 2.6 & 210 \\
\hline Significance & NS & NS & NS & NS & $\mathrm{L}^{* *}, \mathrm{Q}^{*}$ & NS \\
\hline \multicolumn{7}{|c|}{ Season (three harvests) } \\
\hline 0 & 55.5 & 20.6 & 13.2 & 89.3 & 1.2 & 190 \\
\hline 25 & 55.1 & 23.6 & 13.0 & 91.7 & 1.3 & 190 \\
\hline 50 & 55.6 & 21.8 & 11.6 & 89.0 & 2.2 & 195 \\
\hline 100 & 57.0 & 24.4 & 12.5 & 93.9 & 3.2 & 195 \\
\hline 150 & 52.6 & 24.1 & 11.1 & 87.8 & 3.1 & 195 \\
\hline 200 & 56.4 & 23.2 & 11.3 & 90.9 & 3.3 & 190 \\
\hline Significance & NS & NS & NS & NS & $L^{* *}, Q^{*}$ & NS \\
\hline
\end{tabular}

${ }^{2}$ Prate calculated on basis of planting beds on 1.5 -m centers but incorporated in the soil in the raised, mulched bed measuring $15 \mathrm{~cm}$ in height $\times 75 \mathrm{~cm}$ wide.

'Diameter: extra large $(>6.99 \mathrm{~cm})$, large $(6.35-7.06 \mathrm{~cm})$, and medium $(5.72-6.43 \mathrm{~cm})$.

Ns, *, ** Nonsignificant or significant at $P \leq 0.05$ or 0.01 , respectively. Regression equations contained significant linear $(\mathrm{L})$ or quadratic $(\mathrm{Q})$ terms.

whole-leaf $\mathrm{P}$ concentrations with all $\mathrm{P}$ treatments at all sampling periods were within or above published sufficiency ranges of 2 to 4 $\mathrm{g} \cdot \mathrm{kg}^{-1} \mathrm{P}$ for tomato (Hochmuth et al., 1991; Jones et al., 1991) and similar to the P concentration values of tomato leaves at the Boynton Beach site.

These results indicate that tomatoes growing on two soils testing very high in Mehlich$\mathrm{P}$ had adequate $\mathrm{P}$ available to them. The results were the same even though one soil tested near the breakpoint on the Univ. of Florida calibration curve for high-very high oils.

Soil $P$ content. Mehlich-1 tests conducted on soil samples from each site, taken shortly after fertilization and at the end of the season, wed that the $\mathrm{P}$ soil test index increased in Pierce (Table 4). Although extractable P declined during the season in the soil fertilized with $P$, the values after harvest were still very high and were higher than the beginning (unfertilized) $\mathrm{P}$ soil test values, illustrating $\mathrm{P}$ accumulation in these soils, especially where was applied at $100 \mathrm{~kg} \cdot \mathrm{ha}^{-1}$ or more, rates similar to the typical commercial $P$ rate of 90 $\mathrm{kg} \cdot \mathrm{ha}^{-1}$. With no $\mathrm{P}$ fertilizer added, the early weason soil test values at both sites those of the unfertilized soil at the beginning of the season. The small differences in values, e.g., $63 \mathrm{mg} \cdot \mathrm{kg}^{-1}$ at prefertilization and 88 fruits made up $99 \%$ of the early marketable were similar (same soil-test interpretation) to

Table 4. Response to P fertilization of Mehlich-1 extractable soil P concentrations measured twice in each of two tomato experiments in Florida.

\begin{tabular}{|c|c|c|c|c|c|c|c|c|c|c|}
\hline \multirow[b]{2}{*}{ Expt. } & \multirow[b]{2}{*}{ Year } & \multirow[b]{2}{*}{ Location } & \multirow[b]{2}{*}{ Sampling time $\mathrm{y}^{\mathrm{y}}$} & \multicolumn{6}{|c|}{$\mathrm{P}$ rate $\left(\mathrm{kg} \cdot \mathrm{ha}^{-1}\right)^{\mathrm{z}}$} & \multirow[b]{2}{*}{ Significance } \\
\hline & & & & 0 & 25 & 50 & 100 & 150 & 200 & \\
\hline & & & & & & & Extrac & P $(\mathrm{mg}$ & & . \\
\hline 1 & 1995-96 & Boynton Beach & Early & 276 & 340 & 300 & 300 & 400 & 360 & NS \\
\hline \multirow[t]{2}{*}{2} & 1996-97 & Ft. Pierce & Early & 88 & 104 & 102 & 135 & 150 & 150 & $\mathrm{~L}^{* *}$ \\
\hline & & & Late & 73 & 80 & 91 & 104 & 140 & 123 & $\mathrm{~L}^{* * *}$ \\
\hline
\end{tabular}

${ }^{2} \mathrm{P}$ rate calculated on basis of planting beds on $1.5-\mathrm{m}$ centers but incorporated in the soil in the raised, mulched bed measuring $15 \mathrm{~cm}$ in height and $75 \mathrm{~cm}$ wide. ${ }^{y}$ Early $=2$ weeks after planting; late $=$ after last harvest.

Ns, **Nonsignificant or significant at $P \leq 0.01$, respectively. Regression models contained significant linear (L) terms. $\mathrm{mg} \cdot \mathrm{kg}^{-1}$ at early sampling at Ft. Pierce, were probably due to sampling variability. The prefertilization samples were random samples from the experimental area and the early samples were taken from the specific plots with the zero-P treatment. This result is the same as that obtained by Selles et al. (1995) where, in multi-year cropping systems receiving no $\mathrm{P}$, the Olsen $\mathrm{P}$ soil test index remained constant. The Mehlich-1 P index of unfertilized soil also remained unchanged after tomato cropping in another study with tomato in Florida (Shuler and Hochmuth, 1995).

In work with corn and soybean in Minnesota, Randall et al. (1997) measured the decline in soil-test P concentrations over a 20year cropping period, and concluded that growers with soils with high soil-test $P$ need not apply $\mathrm{P}$. With grain crops, most $\mathrm{P}$ is removed from the soil in the harvested grain, assuming erosion is nil and that $\mathrm{P}$ does not leach in most agricultural soils (Barrow, 1980). Rhue and Everett (1987) showed that P could leach on acidic, coarse sandy soils, but liming acidic soils minimized P losses. On the level, heavily limed sandy soils used in these tomato studies, the main avenue for $\mathrm{P}$ loss would be the harvested fruits, an amount reported to be $\approx 50$ $\mathrm{kg} \cdot \mathrm{ha}^{-1}$ (McVickar and Walker, 1978). Potential losses of $\mathrm{P}$ due to leaching from this coarse, sandy soil were not measured and this aspect should be addressed in further research.

In summary, tomato yields and fruit size did not respond to $\mathrm{P}$ fertilization of high- and very high-P soils on two commercial tomato farms in southeastern Florida. Whole-leaf tissue $\mathrm{P}$ concentrations were always more than adequate, showing that plants growing in the unfertilized soil had access to adequate P. Soil test results showed that $\mathrm{P}$ accumulated in these soils during the season and that tomato growth in the unfertilized soils did not affect the soil's $\mathrm{P}$ status. These results clearly show that routine $\mathrm{P}$ applications to soils that test very high in $\mathrm{P}$ are not warranted. Adhering to soil test predictions for $\mathrm{P}$ fertilization would improve tomato production profitability and minimize chances for $\mathrm{P}$ contamination of the environment by leaching to groundwater or erosion transport with soil to surface water bodies.

\section{Literature Cited}

Anderson, C.A. 1983. Comparison of Mehlich-1 and Bray-1 soil tests for phosphorus in citrus groves. Soil Sci. Soc. Florida. Proc. 42:146149.

Barber, S.A. and J.L. Kovar. 1985. Principles of applying phosphorus fertilizer for greatest effi- 
ciency. J. Fert. Issues 2:91-94.

Barrow, N.J. 1980. Evaluation and utilization of residual phosphorus in soils, p. 333-359. In: F.E. Khasawneh et al. (eds.). The role of phosphorus in agriculture. Soil Science Soc. Amer., Madison, Wis.

Fixen, P.E. and J.H. Grove. 1990. Testing soils for phosphorus, p. 141-180. In: R.L. Westerman (ed.). Soil testing and plant analysis. 3rd ed. Soil Sci. Soc. Amer. Book Ser. No. 3, Madison, Wis.

Florida Tomato Commission. 1997a. Annual report, 1996-97. Florida Tomato Comm., Orlando.

Florida Tomato Commission. 1997b. Florida tomato review. Florida Tomato Comm., Orlando. 28(2), Sept. 1997.

Forbes, R.B. and P.J. Westgate. 1962. Utilization of soil phosphorus reserves in old vegetable fields. Soil Crop Sci. Soc. Florida. Proc. 22:69-73.

Georgia Agricultural Experiment Station. 1983. Reference soil test methods for the southeastern region of the United States. Georgia Agr. Expt. Sta. Southern Coop. Ser. Bul. 289.

Hanlon, E.A. and G.J. Hochmuth. 1992. Recent changes in phosphorus and potassium fertilizer recommendations for tomato, pepper, muskmelon, watermelon, and snapbean in Florida. Commun. Soil Sci. Plant Anal. 23:2651-2665.

Hanlon, E., J.G. Gonzales, and J.M. Bartos. 1994. Institute of Food and Agricultural Sciences Extension soil testing laboratory chemical procedures and training manual. Florida Coop. Ext. Serv. Circ. 812.

Hatzell, H. and W.G. Blue. 1981. Predictions of phosphorus requirements of plants on Ultisols with different residual phosphorus contents. Soil Crop Sci. Soc. Florida Proc. 40:83-87.

Hochmuth, G. (ed.). 1990. Tomato production guide for Florida. Florida Coop. Ext. Serv. Circ. 98C.

Hochmuth, G.J., and E.A. Hanlon. 1995. Institute of Food and Agricultural Sciences standardized fertilization recommendations for vegetable crops. Florida Coop. Ext. Serv. Circ. 1152.

Hochmuth, G.J., E.A. Hanlon, and J. Cornell. 1993a. Watermelon phosphorus requirements in soils with low Mehlich-1-extractable phosphorus. HortScience 28:630-632.

Hochmuth, G.J., E. Hanlon, B. Hochmuth, G. Kidder, and D. Hensel. 1993b. Field fertility research with $\mathrm{P}$ and $\mathrm{K}$ for vegetables-Interpretations and recommendations. Soil Crop Sci. Soc. Florida Proc. 52:95-101.
Hochmuth, G. and D. Maynard. 1996. Vegetable production guide for Florida. Florida Coop. Ext. Serv. Circ. SP170.

Hochmuth, G., D. Maynard, C. Vavrina, and E. Hanlon. 1991. Plant tissue analysis and interpretations for vegetables in Florida. Florida Coop. Ext. Serv. Spec. Ser. SSVEC-42.

Hortenstine, C.C. 1966. Phosphorus fixation and phosphorus fractions in sandy soils. Soil Crop Sci. Soc. Florida Proc. 26:136-142.

Jones, J.B., B. Wolf, and H.A. Mills. 1991. Plant analysis handbook. Micro-Macro Publ., Athens, Ga.

Kovar, J.L. and S.A. Barber. 1987. Placing phosphorus and potassium for greatest recovery. J. Fert. Issues 4:1-6.

Kurtz, L.T. 1981. Dismounting from the phosphorous fixation merry-go-round. Soil Crop Sci. Soc. Florida Proc. 40:35-40.

Locascio, S.J., A.G. Smajstrla, and M.R. Alligood. 1996. Nitrogen requirements of drip-irrigated tomato. Proc. Florida State Hort. Soc. 109:146149.

Locascio, S.J. and G.F. Warren. 1960. Interaction of soil temperature and phosphorus on growth of tomatoes. Proc. Amer. Soc. Hort. Sci. 75:601610.

Locascio, S.J., G.F. Warren, and G. Wilcox. 1960. The effects of phosphorus placement on uptake of phosphorus and growth of direct seeded tomatoes. Proc. Amer. Soc. Hort. Sci. 76:503-514.

McVickar, M.H. and W.M. Walker. 1978. Using commercial fertilizers. 4th ed. Interstate Printers and Publishers. Danville, Ill.

Mehlich, A. 1953. Determination of P, Ca, Mg K, $\mathrm{Na}$, and $\mathrm{NH}_{4}$. North Carolina Soil Testing Div. Mimeo, Raleigh, N.C.

National Agricultural Statistics Service. 1990. Agricultural chemical usage. 1990 Vegetables summary. U.S. Dept. Agr. Econ. Res. Serv., Washington, D.C.

Novais, R. and E.J. Kamprath. 1978. Phosphorus supplying capacities of previously heavily fertilized soils. Soil Sci. Soc. Amer. J. 42:931-935.

Peck N.H., G.E. MacDonald, and M. Hemmat. 1987. Cabbage plant responses to residual phosphorus and potassium in the soil and to bandapplied concentrated superphosphate and potassium chloride fertilizers. Agron. J. 79:831837.

Randall, G.W., T.K. Iragavarapu, and S.D. Evans.
1997. Long-term P and K applications: I. Effect on soil test incline and decline rates and critical soil test levels. J. Prod. Agr. 10:565-571.

Rhoads, F.M., E.A. Hanlon, S.M. Olson, and G.J. Hochmuth. 1990. Response of snapbean to N rates and soil-test P and K. Soil Crop Sci. Soc. Florida Proc. 49:10-13.

Rhue, R.D. and P.H. Everett. 1987. Response of tomatoes to lime and phosphorus on a sandy soil. Agron. J. 79:71-77.

Rhue, R.D., D.R. Hensel, T.L. Yuan, and W.K Robertson. 1981. Response of potatoes to soil and fertilizer phosphorus in northeast Florida. Soil Crop Sci. Soc. Florida Proc. 40:58-61.

Sartain, J.B., R.B. Forbes, and N.R. Usherwood. 1979. Yield response of soybeans to $P$ and $K$ fertilization as correlated with soil extractable and tissue nutritional levels. Commun. Soil Sci. Plant Anal. 10:1219-1232.

SAS Institute. 1985. SAS user's guide: Statistics, ver. 5 ed. SAS Inst., Cary, N.C.

Selles, F., C.A. Campbell, and R.P. Zentner. 1995. Effect of cropping and fertilization on plant and soil phosphorus. Soil Sci. Soc. Amer. J. 59:140 144.

Sherman, M. 1990. Harvesting and handling. p. 18 21. In: G. Hochmuth (ed.). Tomato production guide for Florida. Florida Coop. Ext. Serv. Circ. 98C

Shuler, K.D. and G.J. Hochmuth. 1995. Field tests of phosphorus fertilization of tomato growing in high-P soils in Palm Beach County, Florida. Proc. Florida Hort. Soc. 108:227-232.

Smith, S.A. and T.G. Taylor. 1995. Production cost for selected vegetables in Florida, 1994-95. Florida Coop. Ext. Serv. Econ. Info. Rpt. EI 951.

Tisdale, S.L., W.L. Nelson, and J.D. Beaton. 1985. Soil fertility and fertilizers. MacMillan, New York.

Westgate, P.J., R.B. Forbes, and W.G. Blue. 1958. Soil phosphorus reserves in old vegetable fields in the Sanford area. Soil Crop Sci. Soc., Florida. 18:111-115

Witzig, J.D. and N.L. Pugh. 1997. Florida agricultural statistics. Vegetable summary. Florida Agr. Stat. Serv., Orlando.

Wolf, A.M. and D.E. Baker. 1985. Comparisons of soil test phosphorus by Olsen, Bray P-1, Mehlich1 , and Mehlich-3 methods. Commun. Soil Sci. Plant Anal. 16:467-484. 